\title{
Re: Prognostic Relevance of the Histological Subtype of Renal Cell Carcinoma
}

\author{
Marcos F. Dall'Oglio, Alberto A. Antunes, Antonio C. Pompeo, Alcides Mosconi, Katia R. M. Leite, \\ Miguel Srougi
}

Division of Urology, School of Medicine, University of Sao Paulo, USP, Sao Paulo, SP, Brazil

Int Braz J Urol, 34: 3-8, 2008

To the Editor,

Renal cell carcinomas are classified morphologically into 4 major categories by the current World Health Organization classification: clear cell (conventional), papillary, chromophobe and collecting duct (Bellini cell). These tumors seem to behave differently and numerous prognostic factors have been confirmed to be of utility in establishing predictive information, including tumor stage, renal sinus involvement and extra-renal spread. In addition, histopathological parameters have gained acceptance in routine clinical practice, being nuclear pleomorphism grading (in especial the Fuhrman method) one of the most common used. More recently, several studies have shown that chromophobe renal cell carcinoma has a significantly better prognosis than clear cell carcinoma. $(4,7,8)$, with several series showing that this variant has more than $95 \% 5$-year survival. These tumors often present as large masses, but the majority is organ confined (pT3 or pT4 chromophobe tumors are rare). Since morphologically many would qualify as Fuhrman grade 3, the nuclear grading does not reflect their prognosis and its use is not recommended in chromophobe tumors.

The interesting article by Dall'oglio et al describes a contemporary, single-institution series of renal tumors that may represent the largest study in a population from South America. (3) It is a well designed article that should greatly contribute to this interesting area of urological pathology. They found that clear cell, papillary and chromophobe types of renal cell carcinomas had 76.6, 71.1 and 71.2\% and that sarcomatoid differentiation is highly correlated with aggressiveness. The reported relative poor prognosis of chromophobe renal cell carcinomas, however, represents a finding that is discrepant to studies from North America (1), Europe (2), Oceania (5) and Asia (6), when sarcomatoid carcinomas are excluded from the analyses. Several articles assessing prognosis of this subtype have found that even large tumors (mean diameter was $9 \mathrm{~cm}$ in one study) with "high" nuclear grade, behave better than other types. (1) The study brings new data to the discussion and shows that chromophobe renal cell carcinomas can behave bad in either selected populations or clinical scenarios, which remains to be elucidated. The authors raise the possibility that in the Brazilian population presentation at higher stages may contribute to this behavior. What the authors could have told the readers is whether multivariate analyses of the subtypes show prognostic differences independent of size, stage, renal sinus involvement and nuclear grade. Since the authors have retrospectively reviewed all cases, it should be easy to perform this analysis as all the other variables are in the standard pathology report. It would greatly increase the strength of the data and contribute to the better understanding on the behavior of renal cell tumors.

\section{REFERENCES}

1. Cheville JC, Lohse CM, Zincke H, Weaver AL, Blute ML: Comparisons of outcome and prognostic features among histologic subtypes of renal cell carcinoma. Am J Surg Pathol. 2003; 27: 612-24.

2. Cindolo L, de la Taille A, Schips L, Zigeuner RE, Ficarra V, Tostain J, et al.: Chromophobe renal cell 
carcinoma: comprehensive analysis of 104 cases from multicenter European database. Urology. 2005; 65: 681-6.

3. Dall'oglio MF, Antunes AA, Pompeo AC, Mosconi A, Leite KR, Srougi M: Prognostic relevance of the histological subtype of renal cell carcinoma. Int Braz J Urol. 2008; 34: 3-8.

4. Delahunt B, Bethwaite PB, Nacey JN: Outcome prediction for renal cell carcinoma: evaluation of prognostic factors for tumours divided according to histological subtype. Pathology. 2007; 39: 459-65.

5. Delahunt B, Sika-Paotonu D, Bethwaite PB, McCredie MR, Martignoni G, Eble JN, et al.: Fuhrman grading is not appropriate for chromophobe renal cell carcinoma. Am J Surg Pathol. 2007; 31: 957-60.

6. Kim H, Cho NH, Kim DS, Kwon YM, Kim EK, Rha $\mathrm{SH}$, et al.: Renal cell carcinoma in South Korea: a multicenter study. Hum Pathol. 2004; 35: 1556-63.

7. Moch H, Gasser T, Amin MB, Torhorst J, Sauter G, Mihatsch MJ: Prognostic utility of the recently recommended histologic classification and revised TNM staging system of renal cell carcinoma: a Swiss experience with 588 tumors. Cancer. 2000; 89: 604-14.

8. Patard JJ, Leray E, Rioux-Leclercq N, Cindolo L, Ficarra V, Zisman A, et al. Prognostic value of histologic subtypes in renal cell carcinoma: a multicenter experience. J Clin Oncol. 2005; 23: 2763-71.

Dr. Fabio Tavora

The Johns Hopkins Hospital

Baltimore, Maryland, USA

E-mail:ftavora@gmail.com

\title{
Re: Laparoscopic Radical Prostatectomy: Omitting a Pelvic Drain
}

\author{
David Canes, Michael S. Cohen, Ingolf A. Tuerk \\ Lahey Clinic Medical Center, Burlington, Massachusetts, USA
}

Int Braz J Urol, 34: 151-158, 2008

To the Editor,

The placement of a drain post prostatectomy is the subject of much discussion these days. A lot has been made of surgeons moving to the non-drained model of prostatectomy, the goal has been to become less invasive and reduce patient morbidity. In open prostatectomy, the drain is placed via a separate stab incision while in laparoscopic or robotic cases the drain is brought out through a pre-existing port site. In both cases, the drain is usually removed at day one in a simple manner without any additional anesthesia. The purpose of a pelvic drain is to remove the abdominal fluid contents resulting from the surgery.
This can be blood, lymph or urine. The point is what is the downside?

The drain provides an additional source of diagnostic information during the postoperative period and can help early diagnosis of postoperative problems. This is especially important in modern day surgery with patients going home in under 24 hours. Identifying potential bleeding or urinary extravagation can prevent readmissions and potentially more catastrophic complications. While some are proud of not having to use a drain post surgery, I am sure all would agree that they have at times had to place one 